\title{
EL ORIGEN Y DESARROLLO DE LA NOCIÓN DEL “REPORTERO GRÁFICO” EN EL PERÚ Y LA VISUALIDAD DEL TERRITORIO A INICIOS DEL SIGLO XX
}

\author{
ORIGIN AND DEVELOPMENT OF THE NOTION OF THE NEWS \\ PHOTOGRAPHER-REPORTER IN PERU AND THE VISUALITY OF THE \\ TERRITORY AT THE BEGINNING OF THE XXTH CENTURY
}

\author{
Andrés Garay Albújar* y Jorge Villacorta Chávez,*
}

\begin{abstract}
Este artículo propone explorar el surgimiento de la noción del Reportero Gráfico en Perú, así como su primera puesta en práctica, sus características y su aporte a la definición de una visualidad del territorio nacional a través de la cobertura de eventos y asuntos a comienzos del siglo XX. Se revisará bibliografía relacionada a la historia del periodismo peruano, pero fundamentalmente fuentes de época como las publicaciones de Manuel Moral, el fotógrafo y editor, de cuyas revistas Ilustración Peruana, Variedades, y el periódico La Crónica (fundado en 1912), surge y se consolida la noción del reportero gráfico en el Perú.

Palabras claves: Manuel Moral, fotoperiodismo, periodismo, La Crónica, Perú, fotografía, Max T. Vargas, Chambi, Cusco.

This paper explores the emergence of the notion of the news photographer-reporter in Peru, as well as how it came into practice, and what were its characteristics and its contribution to the definition of a visuality of the national territory through the coverage of events and issues at the beginning of the XXth century. It comprises a bibliographical revision of the history of Peruvian journalism but, fundamentally, of original sources such as photographer and editor Manuel Moral's publications, the illustrated magazines Ilustración Peruana and Variedades, and the daily newspaper La Crónica (founded 1912), where the notion of news photographer-reporter first appeared and was shaped.
\end{abstract}

Key words: Manuel Moral, photojournalism, journalism, La Crónica, Perú, photography, Max T. Vargas, Chambi, Cusco.

\section{Introducción ${ }^{1}$}

La figura de Manuel Moral, en tanto fotógrafo y editor, es crucial para entender la creación y el desarrollo de la noción innovadora del reportero gráfico en el Perú. En las publicaciones que creó en Lima entre 1905 y 1912, reconoció y dio cabida a fotógrafos de provincias, renombrados y anónimos, y así hizo posible una convergencia de miradas y de temas que dio como resultado una nueva visualidad: la de una realidad peruana heterogénea y desigual. En el diario La Crónica, la última publicación que fundó (1912), llegaría a consolidar una primera modernidad en nuestra fotografía porque a través de ese medio, que recogía la experiencia en las revistas suyas fundadas años atrás, se ofrecía poder imaginar el Perú y contrastar visiones de su presente y futuro a la luz de su pasado, dando impulso y afianzando una esfera pública burguesa que, gracias a él, supo valorar como nunca antes la imagen fotográfica.

\section{Fotógrafo retratista, negocio y conocimiento del país}

Manuel Moral, portugués de nacimiento, arribó a Perú en 1883, a los 18 años de edad. Por entonces, en el Callao, conoció al fotógrafo estadounidense William Mason, a quien se le atribuye haber sido su mentor en la fotografía profesional. Si bien tuvo su estudio fotográfico en la calle La Misión en el Callao en 1895, Moral empezó a viajar a provincias del Perú con un estudio itinerante denominado "Fotografía Lusitania", marca que creó y bajo la cual realizó inicialmente su trabajo fotográfico de estudio en forma independiente. Con este nombre recorrió diferentes ciudades peruanas, en busca de nuevos mercados (Garay y Villacorta 2014:24). Para darse a conocer empleó el recurso del avisaje en la prensa local, como se ha podido constatar en la ciudad de Piura, al norte del país (La Industria, Piura, 30 de abril 1892) y en la ciudad de Arequipa,

\footnotetext{
* Universidad de Piura, Piura, Perú. Correo electrónico: andres.garay@udep.pe

** Alta Tecnología Andina, Lima, Perú. Correo electrónico: vistacorta@yahoo.es
} 
en el sur andino. Para llegar a un público diverso, empleó el afiche de calle: en una fotografía de la calle Libertad de Piura de Enrique Brüning de 1892, aparecen en una pared los restos de un afiche de "Fotografía Lusitania" (José Cerna Sabogal comunicación personal 2014).

Cuando Manuel Moral instaló temporalmente su estudio fotográfico en Arequipa a inicios de 1898 no imaginó que en esa ciudad conocería a quien se convertiría en uno de los fotógrafos más importantes del Perú, el arequipeño Max T. Vargas. Con él tendría una relación de colaboración profesional en el rubro del periodismo gráfico desde el sur peruano (La Bolsa, Arequipa, 18 de febrero: 1898). Moral dejó Arequipa en setiembre de ese mismo año, anunciando a la ciudadanía a través de un aviso publicado en un diario local, que había hecho el traspaso de las placas negativas de los retratos que había realizado durante esos meses en la ciudad a Max T. Vargas, a quien se tendría que recurrir para futuras órdenes ( La Bolsa, Arequipa, 25 de octubre 1898: 4; y El Deber, Arequipa, 20 de setiembre 1898: 2). De hecho, se había establecido una relación entre ambos que se extendería hasta inicios de la segunda década del siglo entrante.

El primer estudio de Moral en Lima, en la calle Mantas, lo administró en simultáneo con el que tenía en el Callao (Marilú Cerpa Moral comunicación personal 2013). En este periodo (hasta 1903) también puso avisos en la prensa local. Por la fuerte competencia que representaba la alta concentración de estudios fotográficos activos en la Lima cuadrada hacia 1900, se puede deducir que Moral fue muy arriesgado y audaz en abrir su estudio en la calle Mercaderes en 1903, casi frente a la "Fotografía Central", establecimiento fundado por los hermanos Courret y que estaba dirigido por Adolphe Dubreuil (Garay y Villacorta 2014: 24). Además, en esos años estaban activos en el centro de Lima cerca de veinte establecimientos dedicados a la fotografía (José Cerna Sabogal comunicación personal 2014).

La organización del estudio fotográfico, la administración de los servicios de la imprenta, el trabajo editorial y el manejo publicitario fueron aspectos del negocio que él supo armonizar con eficiencia en la última década de su vida.

En la lujosa sala de espera de su estudio se congregaron celebridades, políticos, poetas, intelectuales, periodistas, viajeros y familias de alcurnia limeña. Su espacio de trabajo acogió sonadas tertulias y reuniones sociales. Los retratos de Moral de esta época son imponentes por su tamaño y por la belleza lograda a partir de la apariencia del personaje en retrato individual y armonía de composición en el retrato grupal. Los retratos obtenidos en el estudio fotográfico de las personalidades y notables se publicaban en una sección de Ilustración Peruana que llevaba el título de "Arte Fotográfico".

\section{Moral, editor}

Moral empieza editando revistas ilustradas en perfecta consonancia con la historia del fotoperiodismo, pues para 1905, año en que funda y lanza Prisma, su primera publicación, ya las revistas ilustradas -alemanas, francesas, británicas, italianas, estadounidenses, etc.-, llevaban cerca de dos décadas circulando exitosamente en el mundo, desde los años de 1860 (Newhall 2002:249). Fueron las revistas las que incorporaron activamente y en lugar protagónico a las imágenes fotográficas, a diferencia de lo que ocurrió con los diarios y periódicos que tardaron casi dos décadas en hacerlo medianamente. Puede decirse así que fue en las revistas ilustradas que empezó a gestarse el fotoperiodismo como lo conocemos (aunque pasarían casi cincuenta años más, antes de que surgiera el concepto de contar una historia visualmente usando varias imágenes de un mismo fotógrafo, relacionadas entre sí, lo que hoy conocemos como reportaje gráfico).

Los primeros experimentos de incorporación de una imagen en la página de un diario impreso también ocurrieron en la década de 1880 . Pero fue recién entrada la década de 1890 que la presencia de imágenes impresas se hizo más constante en el tiempo. El primer diario que incorporaba activamente imágenes fotográficas fue el Daily Mirror, aparecido en Inglaterra en 1903. Su contraparte en los Estados Unidos, el Illustrated Daily News de Nueva York, recién apareció en 1919 (Alonso 1995:47).

Moral llega a la fundación de un diario como expresión cabal de periodismo gráfico, al final de su breve carrera como editor, en 1912: La Crónica es un brillante decantamiento de una intensa experiencia recogida editando revistas ilustradas y procesadas con miras a revolucionar la prensa diaria en el contexto peruano.

Pero la historia de Moral con relación al mundo de las publicaciones locales comienza en la última década del siglo XIX: hace su incursión en él como colaborador eventual, como una manera de 
diversificar su producción y actividad de fotógrafo propietario de un estudio de retrato en el Callao. Una de las primeras colaboraciones periodísticas de Moral se dio en el semanario ilustrado limeño Monitor Popular en 1897, con la cobertura de la imponente inauguración de la Plaza Grau en el puerto del Callao (Monitor Popular, Lima, 4 de diciembre 1897). Sería este acontecimiento el precedente a su aproximación al mundo de la edición periodística y prueba de su identificación con elementos emblemáticos de sentimiento e identidad nacional.

Muy probablemente fue inducido a incursionar en el ambiente cultural y periodístico por su suegro, el periodista Julio Santiago Hernández, figura de gran influencia en las altas esferas del poder en el Perú -hombre de absoluta confianza del General Miguel Iglesias, Presidente del Perú entre 1883 y 1886-, con cuya hija, Julia, se había casado Moral en el año 1896 (Majluf y Wuffarden 2001:77). Posteriormente, y también como colaborador, publicaría retratos de personajes como el Presidente Manuel Candamo y el poeta José Santos Chocano en el semanario Actualidades, en 1904 (Gargurevich 2011:97).

Precisamente sería su suegro, Julio S. Hernández, el director de su primera revista, Prisma. El fallecimiento repentino de su suegro en 1906 obligaría a Moral a asumir un mayor compromiso con ese mundo de periodismo ilustrado en el que era un recién llegado. Prisma fue una revista lujosa para la época, con impresión impecable, y que empleaba la tricromía para trabajar imágenes a color que se imprimían "con excelentes prensas para impresión de grabados en colores" (Borda 2013:5), con un tamaño de $32 \times 25 \mathrm{~cm}$. La calidad de la revista le hizo acreedora a una Medalla de Plata en la Exposición Internacional de Milán en 1906. Dejó de circular, sin embargo, en 1907 por "ser demasiado literaria, demasiado severa y escrupulosa, demasiado aristocrática..." (Variedades, Lima, 29 de febrero 1908).

Variedades, creada por Moral en 1908 como la sucesora de Prisma para "ensanchar nuestra esfera de acción", como dice el manifiesto fundacional del número Prospecto, fue una revista ilustrada pensada para un amplio público de lectores. Con un formato más pequeño que Prisma, Variedades, de $25 \times 16 \mathrm{~cm}$, tuvo el respaldo técnico necesario en "talleres bien surtidos para la confección perfecta de fotografías y fotograbados, etc." (Variedades, Lima, 29 de febrero de 1908).
Sin ser una publicación estrictamente periodística, Variedades recogía los hechos más relevantes acaecidos a nivel nacional, desde difusión de riquezas naturales y artísticas, hasta eventos sociales y visitas de personajes ilustres a lugares del interior del país. También informaba, con textos y fotografías, sobre catástrofes y siniestros. Tuvo secciones dedicadas a Artes y Letras, a la información gráfica internacional, caricaturas, deportes, sociedad, comercio, ciencia, moda, sección para fotógrafos amateurs, teatro. Con esta ambiciosa oferta, los editores reflejaban la vastedad de sus propósitos para que la revista Variedades "se ponga en pie de figurar como una de las más importantes de América". Desde el punto de vista de la línea editorial, Variedades valoraba su independencia, considerada como "[...] un tesoro para nosotros porque solo así conservaremos buena armonía con el público, y porque así será más vasto nuestro campo de acción, pues no estará limitado por las conveniencias o simpatías por determinado grupo político" (Variedades, Lima, 29 de febrero de 1908).

De circulación nacional, Variedades se fue convirtiendo en una de las revistas más populares desde su fundación en 1908, hasta su cierre en 1932. En ella se evidencia el buen tratamiento gráfico e informativo mediante la fotografía, enriquecido por la red de colaboradores que había desarrollado Moral a lo largo de la costa, sierra y selva peruanas. El flujo de información que creó Moral en torno a Variedades sería un precedente de lo que sería la definición del diario La Crónica que fundó años después.

El sentido nuevo de Moral en el uso de la imagen fotográfica se vio potenciado en Ilustración Peruana, revista que fundó en enero de 1909 y que era de formato grande (de $33 \times 25 \mathrm{~cm}$ ) y fina impresión. $\mathrm{Su}$ primer director fue Federico Larrañaga. Pero la tragedia llegó nuevamente al grupo de Moral, pues Larrañaga falleció en 1911, sucediéndole en la dirección Clemente Palma, hijo del célebre escritor Ricardo Palma. Este quincenario dejó de publicarse en 1913, pero se aprecia en sus páginas un despliegue gráfico notable con ampliación de temas de interés. Tuvo una sección denominada "Perú descriptivo", que aparecía por capítulos con fotografías e información relacionada a la historia, características geográficas, proyectos de desarrollo, y patrimonios histórico y natural de cada uno de los departamentos del Perú (Figura 1).

En Ilustración Peruana se desarrolló, además, una novedosa sección llamada "Vistas del Perú", 


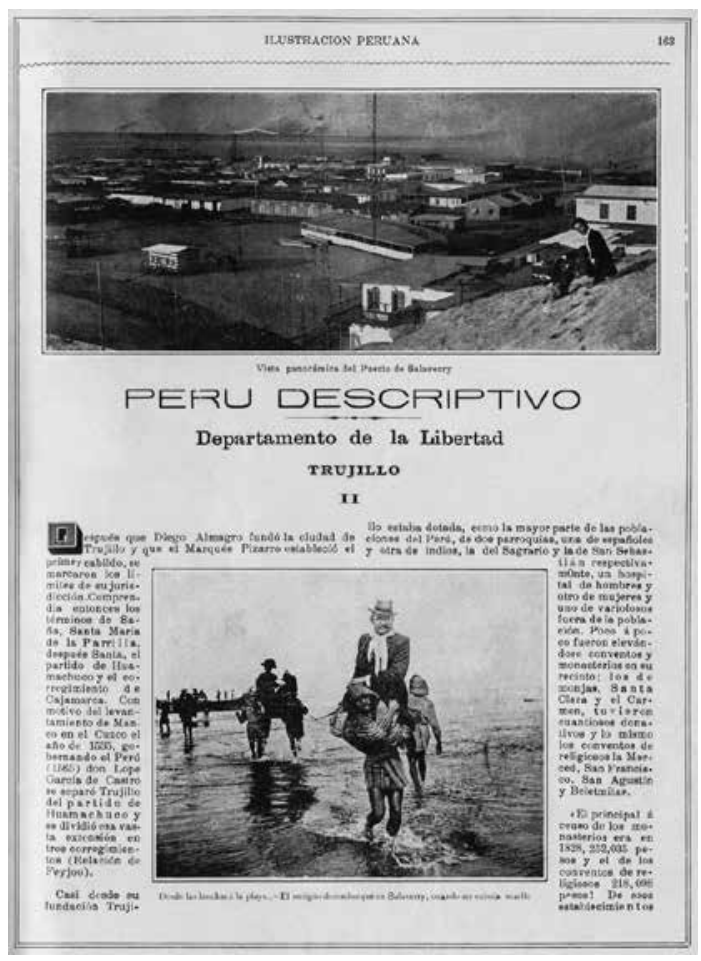

Figura 1. Revista Ilustración Peruana, sección "Perú Descriptivo", Lima, 22 de noviembre de 1912.

que contenía generalmente una fotografía a página entera con una breve leyenda explicativa. Esta sección abarcaba temas como costumbres locales, riquezas naturales, monumentos coloniales y arqueológicos, actividades extractivas, obras de desarrollo (puentes, caminos, expansión ferroviaria, puertos), entre un abanico amplio de temas correspondientes a los acontecimientos que acaecían en el interior del país (Figura 2).

La fotografía como una vía de conocimiento de las dimensiones territoriales y culturales de la nación era una innovación, y como tal empieza a configurarse como uno de los legados más importantes de Manuel Moral. Para los fotógrafos, publicar en Ilustración Peruana y Variedades significaba un afianzamiento de su reputación a nivel de sus localidades y a nivel nacional.

Por ejemplo, el fotógrafo arequipeño Max T. Vargas, quien conocía a Moral desde 1898, empezó a colaborar con sus revistas en 1910 (Borda 2013: 5); publicó una fotografía para la nota "El Halley en Arequipa", de una fotografía tomada, según refiere el texto "a las 5 y 30 de la mañana" (Ilustración Peruana, Lima, 8 de junio 1910). Ese año publica

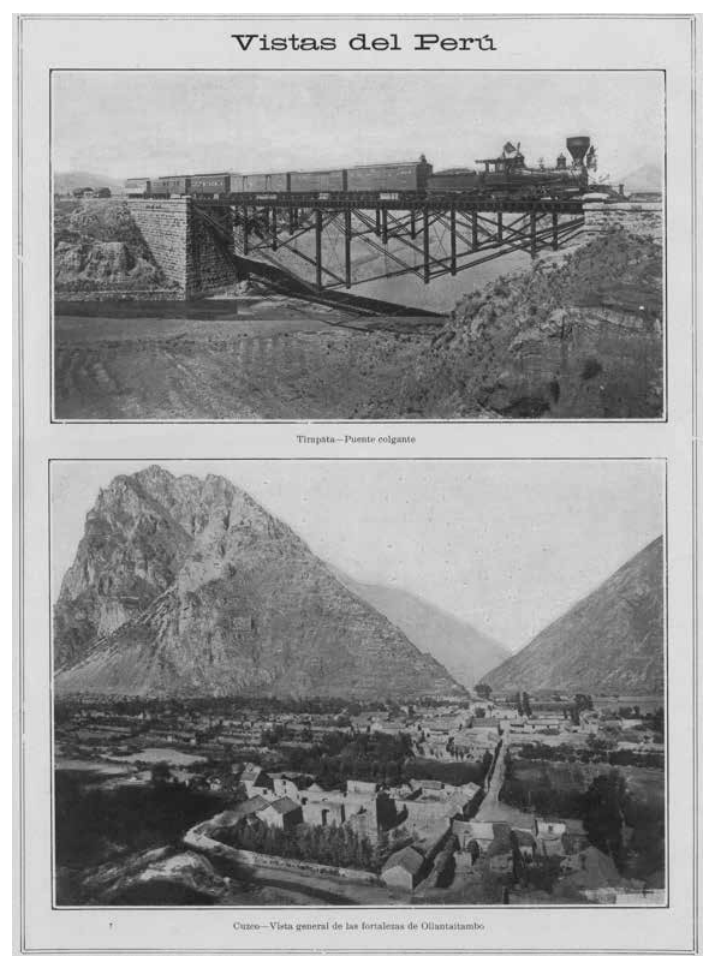

Figura 2. Revista Ilustración Peruana, sección "Vistas del Perú", Lima, 14 de junio de 1911.

un retrato de un indígena bajo el título "Tipo de Indio Cusqueño" y un "Paisaje del Lago Titicaca", en alusión a la cultura nativa que se constituía por esos años como temas de interés tanto turístico como etnográfico (Ilustración Peruana, Lima, 7 de setiembre 1910). En febrero de 1912 Vargas publicó fotografías del Hospital Goyeneche (Ilustración Peruana, Lima, 28 de febrero 1912).

Desde Cusco, se ha ubicado en junio de 1910 la colaboración de Miguel Chani, retratista activo en la ciudad, quien envió imágenes del acontecer público relevante como la "Jura de la Bandera por el Regimiento $\mathrm{N}^{\circ}$ 1" (Ilustración Peruana, Lima, 29 de junio 1910) (Figura 3). Durante estos años hay fotografías publicadas referentes a la extracción del caucho y de oro en la zona de Madre Dios, en la selva sur oriental peruana. Desde Piura, al norte del Perú, el retratista Pedro N. Montero hizo colaboraciones con las revistas de Moral. En 1909 publicó en Variedades un retrato de estudio del "Personal de estudios del Ferrocarril de Paita al Marañón" (Variedades, Lima, 26 de junio 1909). También publicó en 1910 en Ilustración Peruana dos fotografías de tipo documental en la sección 


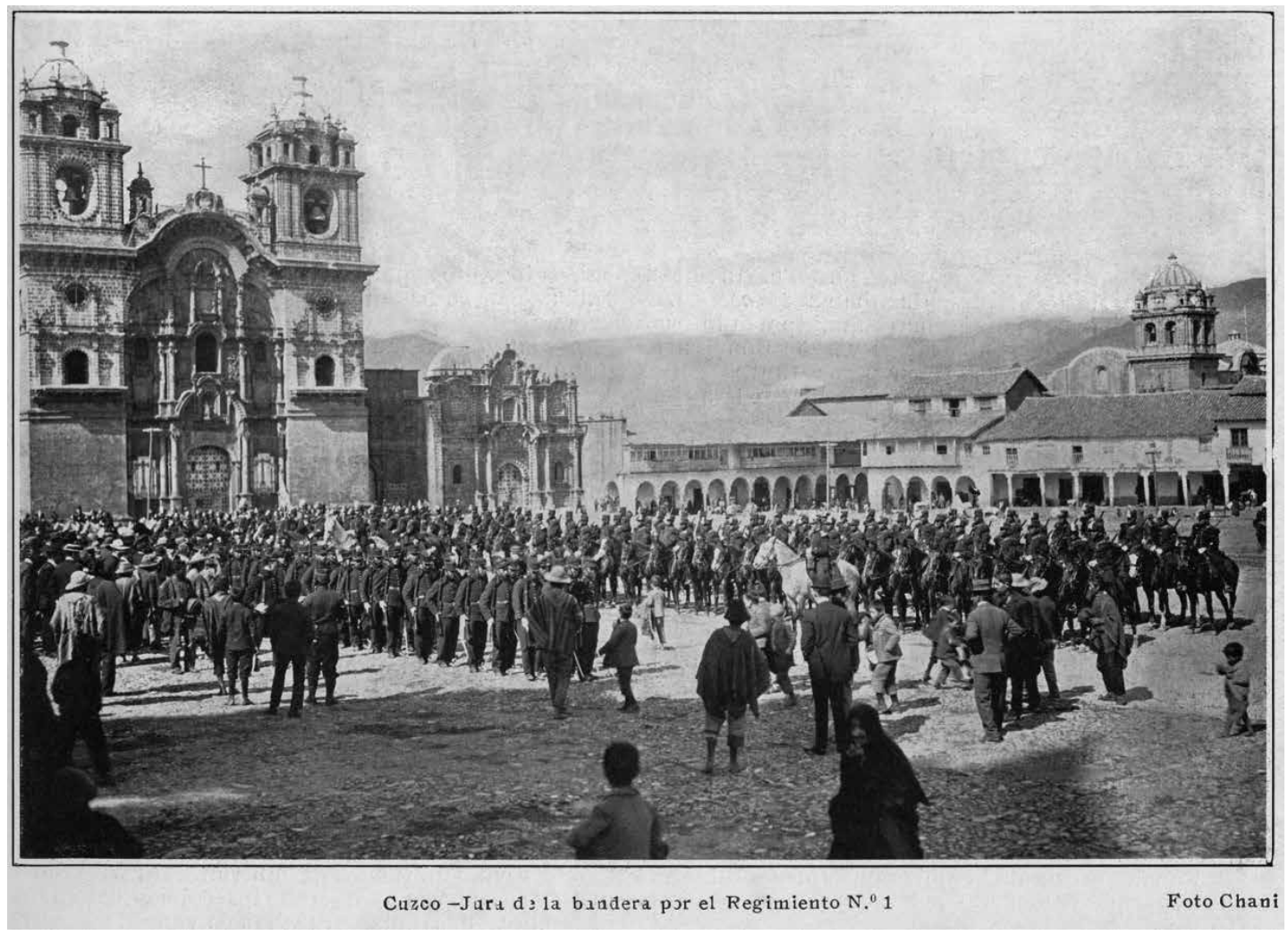

Figura 3. Revista Ilustración Peruana, Lima, 29 de junio de 1910.

"Paisajes y costumbres criollas", con lavanderas a la orilla del río Piura y niños llevando agua en cántaros sobre burro (Ilustración Peruana, Lima, 3 de agosto 1910) (Figura 4).

El flujo de imágenes fotográficas que se creó a través de Ilustración Peruana y Variedades sobre el Perú dio visualidad permanente a las características geográficas, industriales, culturales y sociales del país.

En la ciudad de Lima, Manuel Moral contaba con un grupo de fotógrafos que trabajaban en las coberturas en la capital para sus revistas Ilustración Peruana y Variedades. Entre ellos estaban Elías Del Águila y Fernando Lund, quienes se formaron bajo la dirección directa de Manuel Moral (Majluf y Wuffarden 2001:77). Según Gargurevich, en las revistas se cita como fotógrafos a "[...] Benjamín Valverde, Fausto Grandjean, Alberto Álvarez y Manuel Reaño" (Gargurevich 2011:102). En mayo de 1909 la revista Variedades incorporó en sus filas al fotógrafo Fernando Garreaud, considerado en esa época como reputado artista de la fotografía, situación que reflejaría la capacidad empresarial de Moral al asociarse con otros fotógrafos para darse abasto ante la demanda de la clientela que acudía a su estudio de la calle Mercaderes, hoy Jirón de la Unión (Variedades, Lima, 29 de mayo de 1909).

El 29 mayo de 1909 sería una fecha en la que ocurrió un incidente desde el cual surge la figura del primer mártir de la fotografía de prensa en el Perú. Sucedió que un grupo de opositores al presidente Leguía tomó el Palacio de Gobierno y capturó al mandatario llevándolo a rastras por las calles del centro de Lima hasta la plaza del Congreso. Mientras forzaban al presidente a que firmara su renuncia, aparecieron los soldados y se generó una balacera. En ese fuego cruzado murieron varias personas, entre ellos Enrique Moral, hermano de Manuel, quien estaba haciendo la cobertura fotográfica para la revista Variedades.

En la edición extraordinaria de Variedades del 3 de junio de aquel año se publicaron fotografías realizadas por sus colaboradores y aficionados, y también las fotografías de la cámara del caído Enrique Moral (Gargurevich 2011:102). Por tanto, 


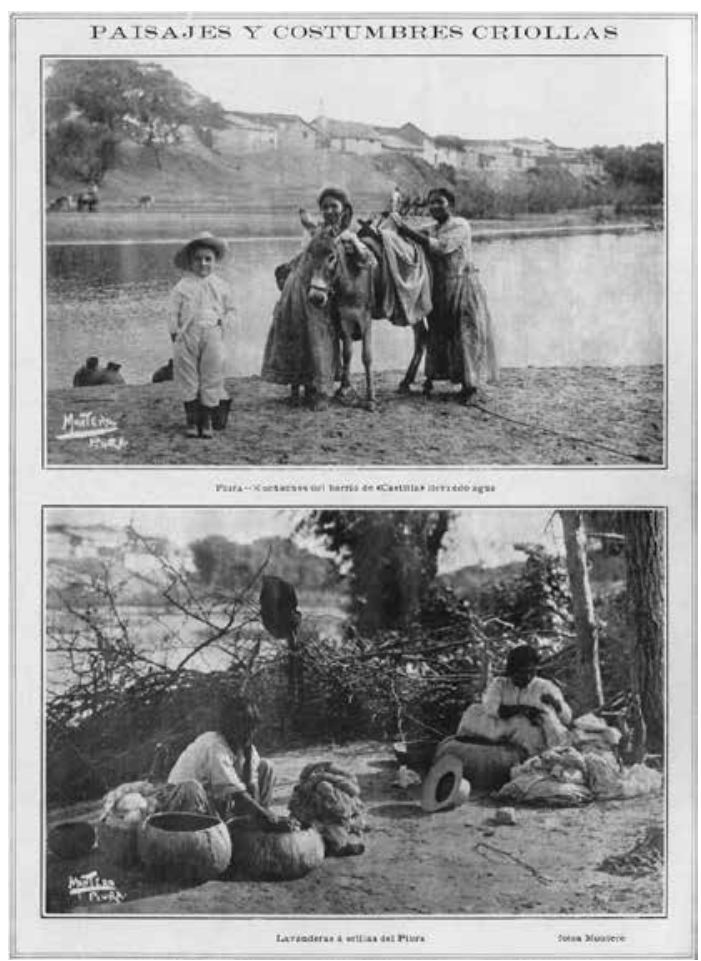

Figura 4. Revista Ilustración Peruana, Lima, 3 de agosto de 1910.

como propone Gargurevich, "Enrique Moral podría entonces ser llamado, con justicia, el primer mártir del fotoperiodismo en el Perú" (Gargurevich 2011:102). Este acontecimiento comprueba el compromiso que tenía Manuel Moral con el periodismo y, especialmente, con la información gráfica.

\section{La Crónica: el reducto de la fotografía informativa}

La última publicación que fundó fue el diario $\mathrm{La}$ Crónica en 1912, medio que impulsó notablemente el periodismo ilustrado peruano, y cuyo primer número apareció el "7 de abril de 1912, con Clemente Palma como director y José Gálvez como jefe de redacción" (Borda 2013:5). La Crónica cosechará la experiencia de Moral en el mundo de las ediciones y el manejo informativo y gráfico que desarrolló en los años de Prisma, Ilustración Peruana y Variedades. De hecho, el día 6 de abril de 1912 la revista Variedades anunciaba escuetamente bajo el titular "La Crónica", que "[...] desde mañana, aparecerá este interesantísimo diario ilustrado, independiente, con profusión de finos grabados, magnífico material de lectura, y cuyo elegante formato y presentación, ha de agradar seguramente a sus favorecedores" (Variedades, Lima, 6 de abril de 1912).

La Crónica aprovecharía la red de colaboradores en corresponsalía y en fotografía con la que ya se contaba a nivel nacional. En el local del diario en Lima se recibía cuantioso material fotográfico de los puntos más alejados del país. Los talleres de impresión contaban con maquinaria renovada y operadores de experiencia, con los que se lograba buena calidad en las planchas de impresión por procedimiento de fotograbados, y conocimientos de diferentes tipos de papel y tintas, factores técnicos importantes para el logro de impresiones seriadas (Alonso 1995:171). Los espacios publicitarios eran contratados por las empresas limeñas con antelación. En este aspecto también se contaba con la experiencia comercial previas de las revistas.

El desafío de Manuel Moral al dar el paso de fundar La Crónica, por tanto, era mantener en sus lectores el interés diario por la actualidad. Y así, el diario se convirtió para los limeños en el eje de la noticia, fue la vibración diaria del acontecer político, cultural, policial, artístico y deportivo (Fernández 1982:5). El uso de la fotografía fue de crucial interés, porque se da un paso de innovación respecto a sus propias revistas y a la prensa nacional, ya que en el contexto de los periódicos de la época ninguno como La Crónica desarrolló un "despliegue de fotograbados y fotografías que llenaban totalmente la portada" (Mendoza 2013:167).

El lugar central de la fotografía en la concepción de Moral como editor fue insólito para la época: publica en las primeras planas imágenes fotográficas a página completa generalmente, y se asegura de agenciar información y sensaciones visuales nuevas para el gran público, ampliando ese concepto gráfico a las contraportadas. Gracias a las revistas ilustradas que había editado, el público ya estaba habituado a la importancia de las fotografías y la calidad de los textos. El uso de la fotografía en 1912 a toda portada -y a toda contraportada, eventualmente-, en un contexto en que otros medios impresos no incluían imagen alguna, evidencia en Moral la perfecta comprensión que tuvo de la presencia de la fotografía como factor de innovación en su diario. Con esta noción conseguía la atracción visual para el comprador y para el lector, estableciendo una jerarquización de la información y una estética nueva en el diseño de la portada y contraportada; con ello lograba una imagen y estilo del propio periódico (Alonso 1995:196). 
Es oportuno indicar que el uso de la fotografía en la prensa peruana se rastrea hasta 1898 en el diario El Comercio, y en otras revistas como Lima Ilustrada (1889), e incluso en las mismas revistas de Moral, con fotografías sobre hechos noticiosos. Pero su uso hasta entonces era irregular, infrecuente, y la portada no era un espacio aprovechado para la imagen fotográfica (Gargurevich 2011: 97). Otros periódicos y revistas de esa época también carecían de una presencia determinante de la fotografía en sus páginas. El mismo diario El Comercio y su competidor el diario La Prensa (1903), y más adelante La Nación (1913) y El Peruano, por citar algunos, así como las revistas Actualidades (1904) y ;Cinema! (1908) incluían algunas veces grabados y dibujos, pero sus diseños no privilegiaban el valor visual de las fotografías (Sánchez 2009:43). Más bien, La Prensa, por ejemplo, empezó a incluir anuncios publicitarios o promociones en la portada sustituyendo esporádicamente a la información noticiosa (Mendoza 2013: 165). En el plano de los diarios, el uso de las fotografías en el diario La Crónica innovador. Este diario es considerado como el primer diario tabloide ilustrado y popular del país, de 39 × $28 \mathrm{~cm}$ (Gargurevich 2011:101).

Con el diario La Crónica se marca un hito en el imaginario colectivo y en la historia de la fotografía peruana. Como editor, Moral reconoció a la fotografía como un medio atractivo, de fácil descodificación por su propia naturaleza visual, noción claramente propia de la modernidad. Su experiencia y reputación como fotógrafo debió ser determinante en esta valoración. Fue consciente que el contenido fotográfico contribuía al conocimiento visual del país, como lo había comprobado en Ilustración Peruana y en Variedades. Pero además de ello, en La Crónica se publicaban hechos de interés político y social, además de los temas que encajaban dentro de la concepción de actualidad nacional e internacional, con noticias cortas y entrevistas diversas (Mendoza 2013:168).

El encabezado De la República en la primera plana da cuenta de ello. Moral proponía a que se consolidara en la esfera pública al Perú como una nación por descubrir, lo que representaba definitivamente un desafío y una novedad entrada la segunda década del siglo XX. Él proveía de información gráfica privilegiada de lugares lejanos del territorio donde existía un mismo sentimiento y una misma preocupación por lo nacional. La celebración de las Fiestas Patrias en la cima de una montaña rocosa de alta riqueza mineral denominada "Maman Vinchus", a 17.000 pies en Cerro de Pasco, con la colocación de las banderas peruanas por un puñado de hombres, refleja el sentido de pertenencia y orgullo por la riqueza natural que provee el territorio andino (La Crónica, Lima, 2 de setiembre 1912) (Figura 5).

Una de las portadas de octubre de 1913, bajo el titular "En las montañas del Perú", publica dos fotografías provenientes de la selva del Perené y, aunque en una se ven las banderas peruanas, lo que sugiere un tiempo de festividad patria, la información que se resalta en la leyenda es sobre la labor y logro de la catequesis llevada a cabo por el padre Hormaechea [sic] en la zona del Perené de San Luis de Shuaro. A través de esta actividad se pudo hacer convivir a dos comunidades nativas oriundas de la selva, los Amueshes [sic] y los Campas (La Crónica, Lima, 18 de octubre 1913) (Figura 6).

De hecho, los fotógrafos ubicados en diversas localidades del Perú, unos anónimos y otros identificados, vieron impresas en las páginas de La Crónica sus fotografías del estado de las cosas en sus localidades. Ellos hacían las imágenes y mostraban lo que veían; Manuel Moral escogía,
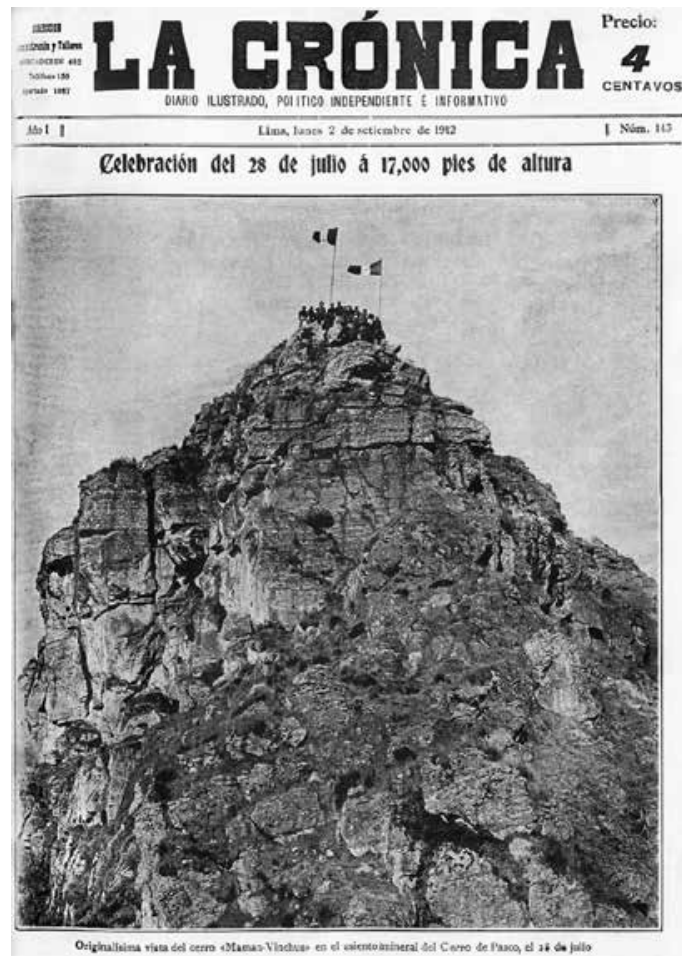

Figura 5. Diario La Crónica, Lima 2 de septiembre de 1912. 

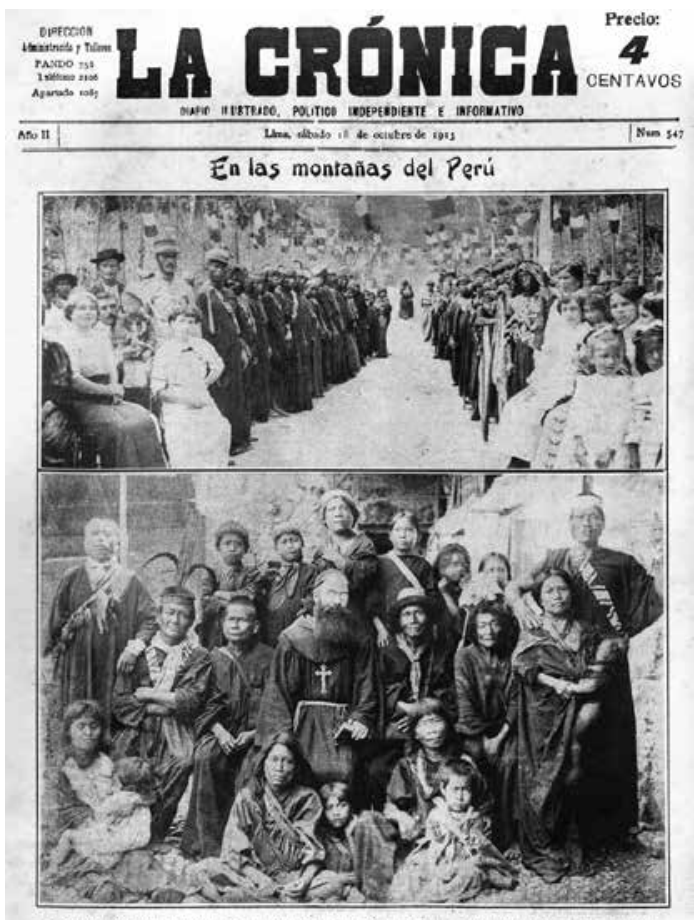

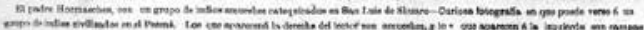

Figura 6. Diario La Crónica, Lima, 18 de octubre de 1913.

ordenaba y publicaba. De este trabajo de reconocer datos, organizarlos y difundirlos podemos inferir que esta labor de Moral modela la modernidad fotográfica en el Perú bajo la noción de la fotografía como documento con carga informativa.

La publicación de imágenes fotográficas favoreció a que los rasgos del país pudieran ser reconocidos, reflexionados, analizados y problematizados en la esfera pública burguesa, al interior de la cual los intelectuales no alineados con el poder eran la facción crítica. Por La Crónica, por ejemplo, se obtuvo un conocimiento visual del movimiento político en Trujillo, ciudad al norte de Lima, acaecido en julio de 1912, en donde la población salió a las calles a protestar contra el fraude electoral y a favor de la presidencia de don Guillermo Billinghurgst (La Crónica, Lima, 11 de julio de 1912) (Figura 7).

\section{Manifiesto a favor del "reportero gráfico"}

El compromiso por la información gráfica por parte de La Crónica fue explícito, en lo que constituye la esencia de la innovación en el uso de la fotografía en la prensa (Borda 2014: 5). Esto se

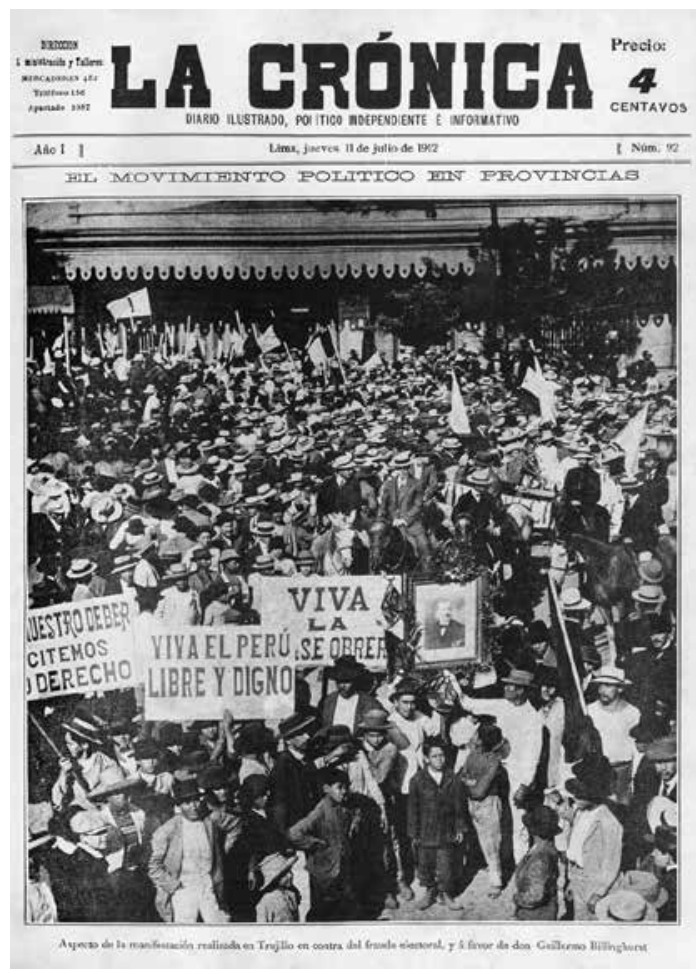

Figura 7. Diario La Crónica, Lima, 11 de julio de 1912.

hizo evidente en un editorial del diario al mes de haberse fundado:

En todos los países donde existe una prensa bien organizada, el "reporter gráfico" [ $\mathrm{sic}]$ es rueda esencial e imprescindible de su mecanismo informativo, y la sociedad que se da cuenta de esta importancia, presta al fotógrafo de prensa todas las posibilidades necesarias para el cumplimiento de su misión (La Crónica, Lima, 17 de mayo de 1912).

Esta declaratoria estuvo respaldada por la reputación de las revistas de Moral en tanto el valor en el tratamiento de la información gráfica con un repertorio amplio de temas peruanos, como en la acogida a un contingente de fotógrafos activos en el interior del país. En La Crónica se inicia una primera formulación de principios y formalización de la profesión del reportero gráfico, del fotoperiodista, y lo concerniente a las condiciones de trabajo como tal. En esta línea de dar peso formal a la actividad del fotógrafo de prensa vinculados a las publicaciones de Moral se hizo explícito en el siguiente manifiesto: "Los reporters fotográficos 
[sic], colaboradores y agentes, están provistos de las credenciales correspondientes y se ruega no atender a quienes no las presenten" (Mendoza 2013:172).

El desafío que planteaba La Crónica fue el sentido de primicia, y por ello impulsó a los fotógrafos colaboradores fotografiar hechos inéditos. En este punto, el ejemplo que grafica la intención del fotógrafo del interior del país por fotografiar hechos relevantes para La Crónica, fue el del fotógrafo arequipeño Max T. Vargas, quien, siendo un reputado artista del retrato y fotógrafo activo en Perú y Bolivia, desarrolló esta faceta de fotografía de prensa acorde al concepto implantado por Manuel Moral en Lima.

La Crónica significó en el Perú un adelanto en la fotografía de prensa que Max T. Vargas no desaprovechó. Un tema de impacto nacional, como el devastador incendio del puerto de Mollendo, acaecido el 2 de abril de 1912, se publicó en paralelo en la revista Variedades y en el diario La Crónica, usando ambos medios las fotografías de Max T. Vargas. La nota de Variedades indicaba que a través de las fotografías de la catástrofe de Mollendo:

[...] puede verse el lamentable estado en que ha quedado aquel importante puerto de la República [...] La resonancia de este hecho que ha repercutido tan dolorosamente en todas partes, nos releva de muchos comentarios sobre la situación especial en que queda todo el comercio del sur [...] Aún no se sabe con seguridad qué medidas se tomarán para evitar los perjuicios que el malestar de Mollendo causan a tan importante sección del territorio, con la nota agravante de tratarse de un puerto que sirve también al comercio de Bolivia (Variedades, Lima, 13 de abril de 1912).

Si bien fueron cuatro fotografías de Max $\mathrm{T}$. Vargas las que se publicaron en el interior de Variedades, estas representan una ampliación de la noticia porque salieron en la edición del día 13 de abril, mientras que La Crónica ya había informado el día 10 de abril, a tres días de su fundación, con dos fotografías de Vargas a portada completa bajo el titular "La Catástrofe de Mollendo" (La Crónica, Lima, 10 de abril de 1912) (Figura 8). Es importante recalcar que los días transcurridos entre el 2 de abril, que fue el incendio, y el día 10 de la primera publicación, fue el tiempo que se tardó el envío en

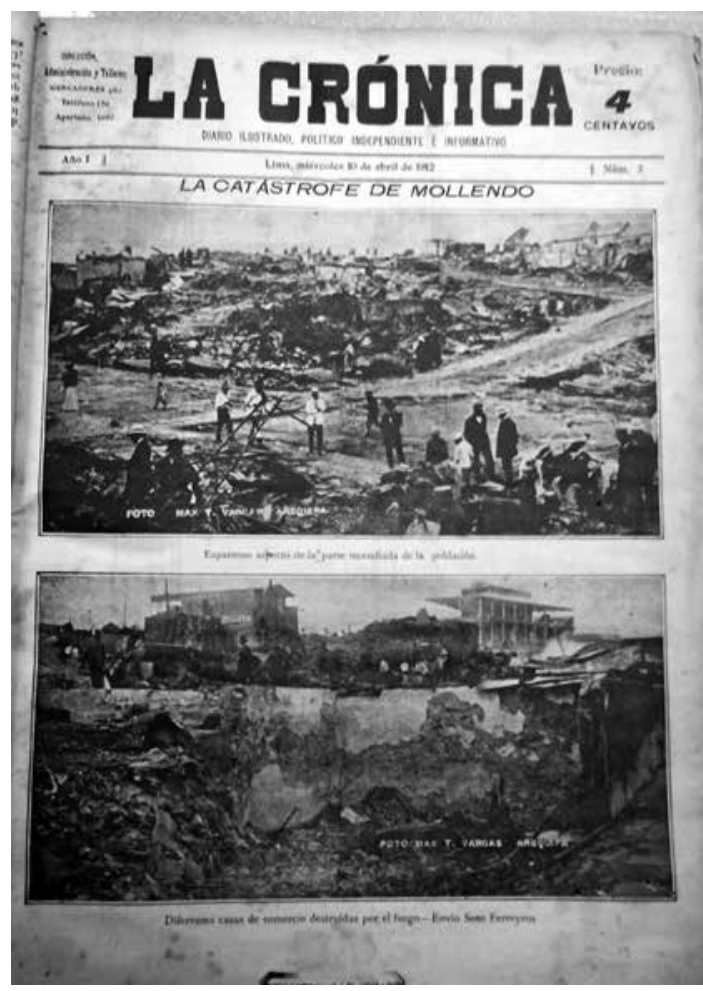

Figura 8. Diario La Crónica, Lima, 10 de abril de 1912.

físico por vía marítima del material periodístico desde Mollendo al Callao y finalmente a Lima. Esto evidencia un entendimiento de periodismo moderno en relación al valor de la actualidad y necesidad por la imagen informativa porque las fotografías se publicaron el 10 de abril, ocho días después del incendio. Además, el diario se había fundado tan solo unos días atrás, el día 7 de abril. De hecho, la portada completa con la información gráfica era una novedad sin precedentes en el periodismo nacional y para el público, perfilando así su propio estilo y sello de identidad.

Parece ser que Max T. Vargas se hizo presente en Mollendo al día siguiente de ocurrido el siniestro porque las imágenes publicadas fueron hechas de día. Ellas muestran la dimensión de los escombros que dejó el incendio en los espacios donde ocurrió: el fuego arrasó con siete manzanas del puerto. El uso de los planos y la comparación de las escalas con la presencia de personas contribuye a que el espectador se sitúe en el contexto.

Pero, justo al año siguiente, el 8 de abril de 1913, el puerto de Mollendo de Arequipa sufrió otro incendio, no tan catastrófico como el de 1912, pero que dejó enormes pérdidas. Max T. Vargas fue 
a Mollendo -o probablemente estaba ahí- y fotografió la voracidad de la llamas de fuego en plena noche. La Crónica publicó tres fotografías suyas en la portada del 20 de abril de 1913, bajo el titular "Momentos álgidos del incendio de Mollendo", con la siguiente leyenda:

Las vistas que publicamos han sido tomadas por el fotógrafo señor Vargas, en los momentos álgidos del incendio de Mollendo, cuando las llamas devoraban manzanas que han quedado completamente destruidas. El espectáculo, como puede juzgarse en estos nítidos fotograbados, fue imponente y terrible. Fotos Vargas (La Crónica, Lima, 20 de abril de 1913).

Este tipo de fotografía es un material que se valora por su alto nivel testimonial registrado directamente sobre el acontecimiento (Figura 9). La lentitud de la llegada de las fotografías en físico desde el punto de origen de la toma hasta los talleres gráficos en Lima no le restaba actualidad ni valor informativo (Alonso 1995:92). La calidad de las fotografías, en cualquier caso, era evaluada por
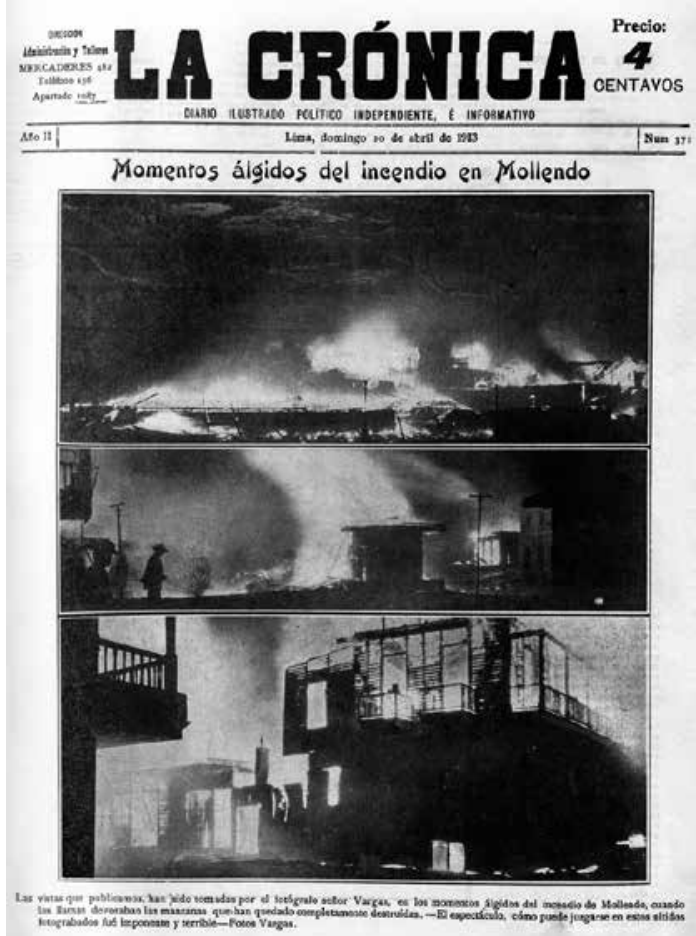

Figura 9. Diario La Crónica, Lima, 20 de abril de 1913.
Moral, quien podía constatar el control de la luz y el copiado en papel fotográfico por parte del autor independientemente de lo previsible o no que pudo haber sido el acontecimiento.

El fotógrafo piurano Pedro N. Montero, que era colaborador con las revistas Variedades e Ilustración, ejemplifica la adhesión de los fotógrafos de provincias del norte peruano con La Crónica. Montero registró sistemáticamente el desastre del terremoto que sufrió la ciudad de Piura el 24 de julio de 1912, consciente del interés noticioso que aportaría a La Crónica y a la revista Variedades (Cerna et al. 2012: 11).

La Crónica publicó en la portada del 8 de agosto una sola fotografía de Pedro Montero un interior que sintetizaba la magnitud del destrozo ocasionado por el terremoto (La Crónica, Lima, 8 de agosto de 1912). Se trata de una vista de lo que quedó de la Iglesia Matriz de Piura (Figura 10). Una imagen altamente descriptiva, lograda desde un punto de vista que permite ver los escombros y los daños en la estructura. En la edición del 11 de agosto aparecieron dos fotos en portada sobre el terremoto, siendo una de ellas la de los daños del Gran Hotel, de Pedro N. Montero (La Crónica, Lima, 11 de agosto de 1912).

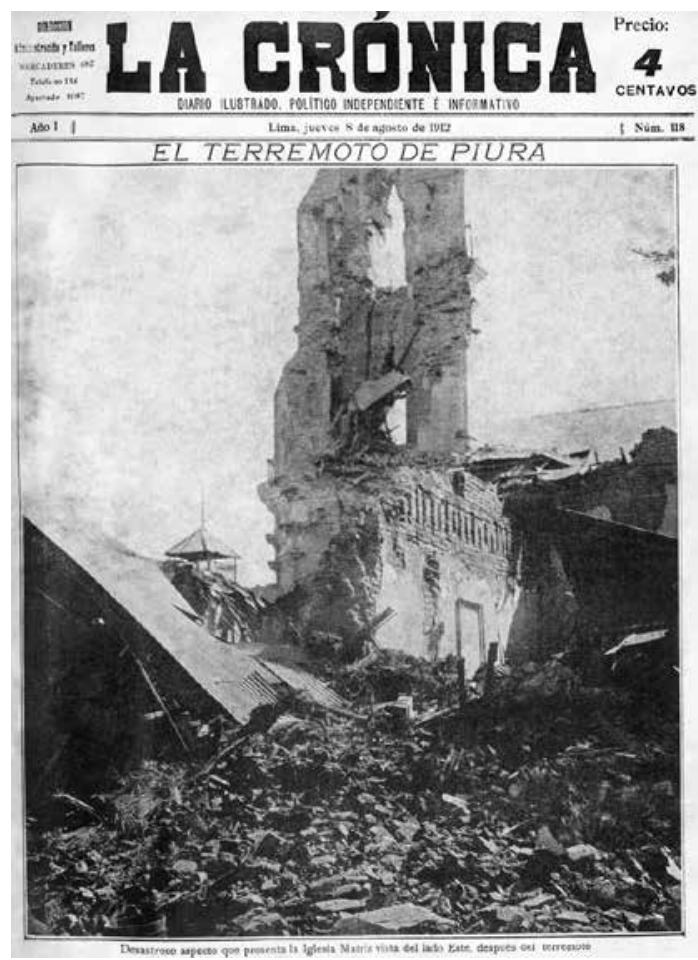

Figura 10. Diario La Crónica, Lima, 8 de agosto de 1912. 


\section{La vigencia de la noción del "reportero gráfico" creada por Moral}

El perfil del fotógrafo en la época era el de un profesional dedicado generalmente a la fotografía de retrato, actividad que le permitía tener ingresos económicos de modo regular. Pero al existir la posibilidad de publicar con cierta regularidad, este fotógrafo afinaba su talento desarrollando una mirada informativa, aquella que detecta temas en su entorno de interés nacional. A los fotógrafos más experimentados y reputados, aquellos que comprendían la cámara fotográfica más allá de sus usos artísticos en retrato y paisajes para postales, las publicaciones en prensa los ejercitó en una fotografía de tipo informativo y documental. Además estaba el añadido de la aparición de la firma o el reconocimiento del crédito en las publicaciones. Manuel Moral, por tanto, sentó las primeras bases prácticas para la función de fotorreportero en un momento como 1912, en que esta profesión no existía como tal.

Esta estrategia de Moral, que generaba material fotográfico de fotógrafos que hacían las veces de corresponsales gráficos en sus localidades y lo que le permitió priorizar la presencia de la fotografía informativa en las cubiertas de La Crónica, pervivió durante muchos años más a su fallecimiento, acaecido súbitamente en noviembre de 1913. La Crónica siguió con este modelo por el lapso de treinta años, un modelo "cuyo factor gráfico se mantuvo de manera predominante y distintiva" (Mendoza 2013:168).

Durante ese periodo que alcanzaría a los inicios de los años de 1930, el concepto gráfico predominante de La Crónica convirtió en una plataforma donde los fotógrafos mostraban imágenes insólitas de diferentes lugares del Perú. Es el caso en 1912, por ejemplo, del fotógrafo anónimo que publicó dos fotografías de nativos de la selva central (Junín) en portada (La Crónica, Lima, 23 de setiembre de 1912) (Figura 11). O el ejemplo del fotógrafo Juan Manuel Figueroa Aznar, asentado entre Cusco y Paucartambo, quien publicó una notable fotografía en 1927 en la bocatoma de un túnel en las montañas de Paucartambo (La Crónica, Lima, 12 de junio de 1927) (Figura 12).

Pero el ejemplo emblemático se ve en un fragmento de la obra del maestro Martín Chambi, aquella relacionada a su actividad de "corresponsal gráfico" en Cusco. Desde que se independizó en 1918 de sus maestros arequipeños para instalarse, primero,

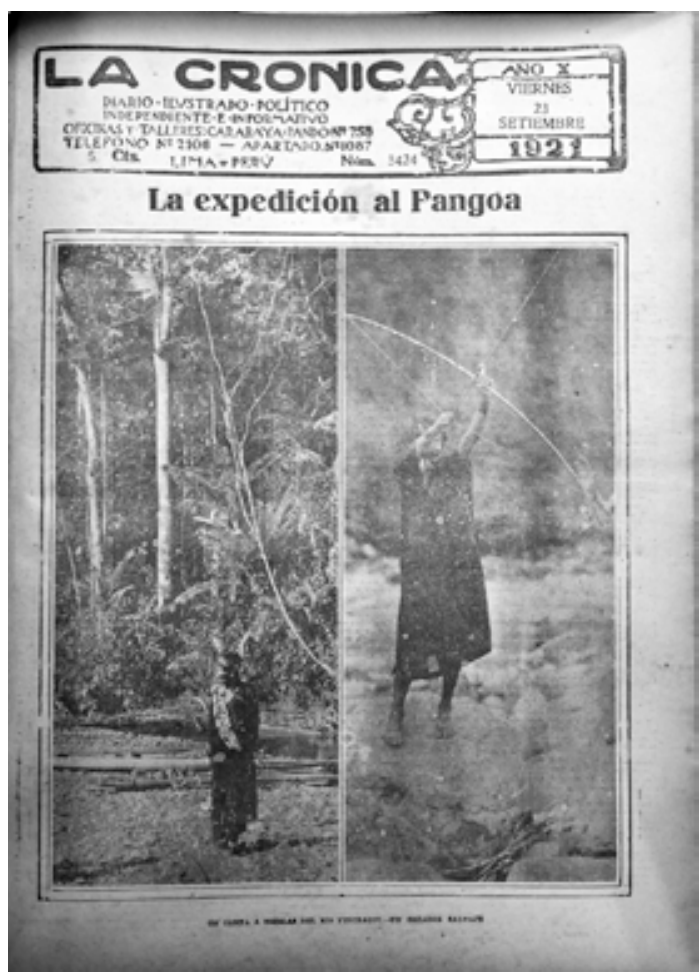

Figura 11. Diario La Crónica, Lima, 23 de setiembre de 1912.

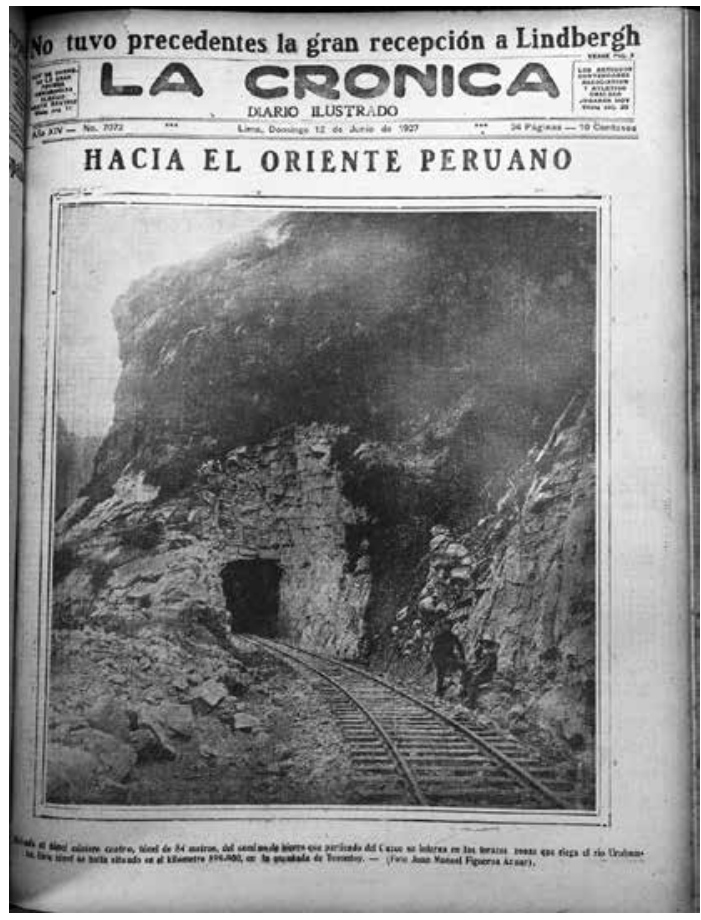

Figura 12. Diario La Crónica, Lima, 12 de junio de 1927. 
en Sicuani y, luego, en Cusco, desarrolló desde el sur andino peruano colaboraciones frecuentes para Variedades y para La Crónica (Schwarz 2007:42). Chambi fue discípulo de Max T. Vargas entre 1908 y 1912, y fue con él donde aprendió esta práctica fotográfica. La acuciosidad del investigador Herman Schwarz lo llevó a determinar que Chambi publicó 59 fotografías en La Crónica entre el periodo de 1918 y 1929, de las cuales 22 fueron motivos de portadas (Schwarz 2007:42).

En lo que podríamos llamar coberturas de hechos noticiosos, Martín Chambi fotografió la primera llegada del avión a Cusco en "iTriunfos del aviador Rolandi!" (La Crónica, Lima, 19 de junio 1921) (Figura 13); "El progreso ferrocarrilero en el Perú" (La Crónica, Lima, 21 de setiembre 1921) (Figura 14); "Nuevo Cuartel en el Cuzco" (La Crónica, Lima, 19 de julio de 1924) (Figura 15); y fotografías de la visita a Machu Picchu de "El Embajador americano visita las ruinas imperiales" (La Crónica, Lima, 8 de junio de 1924) (Figura 16). También se informó a toda portada con fotografía de retrato hecho por Chambi de la inesperada muerte en Puno del aviador Alejandro Velasco Astete, con el titular "El duelo de la aviación peruana" (La Crónica, Lima, 29 de

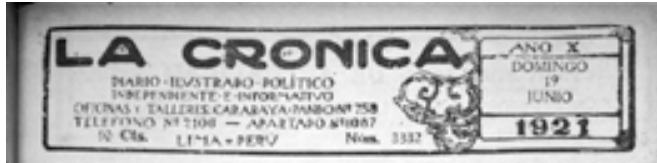

\section{LOS TRIUNFOS DEL AVIADOR ROLANDI}

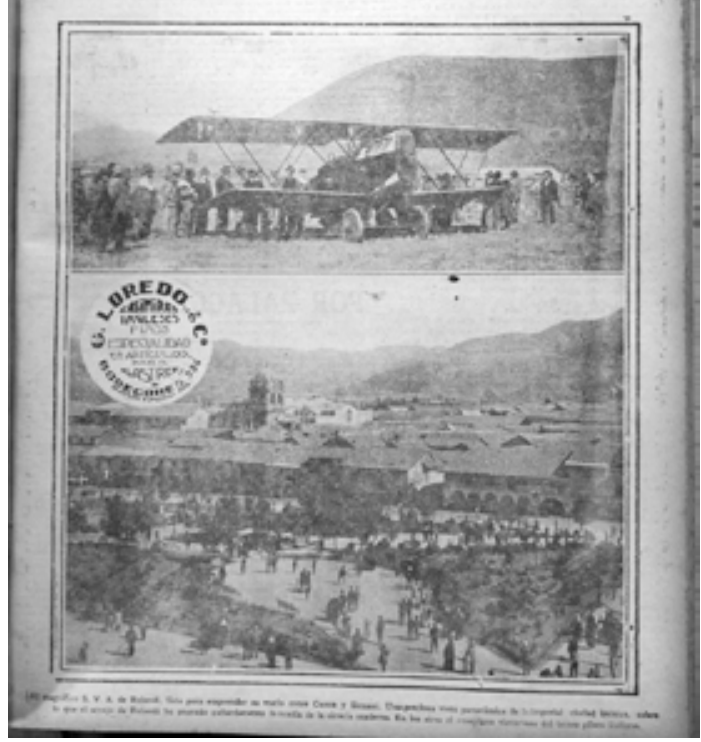

Figura 13. Diario La Crónica, Lima, 19 de junio de 1921.

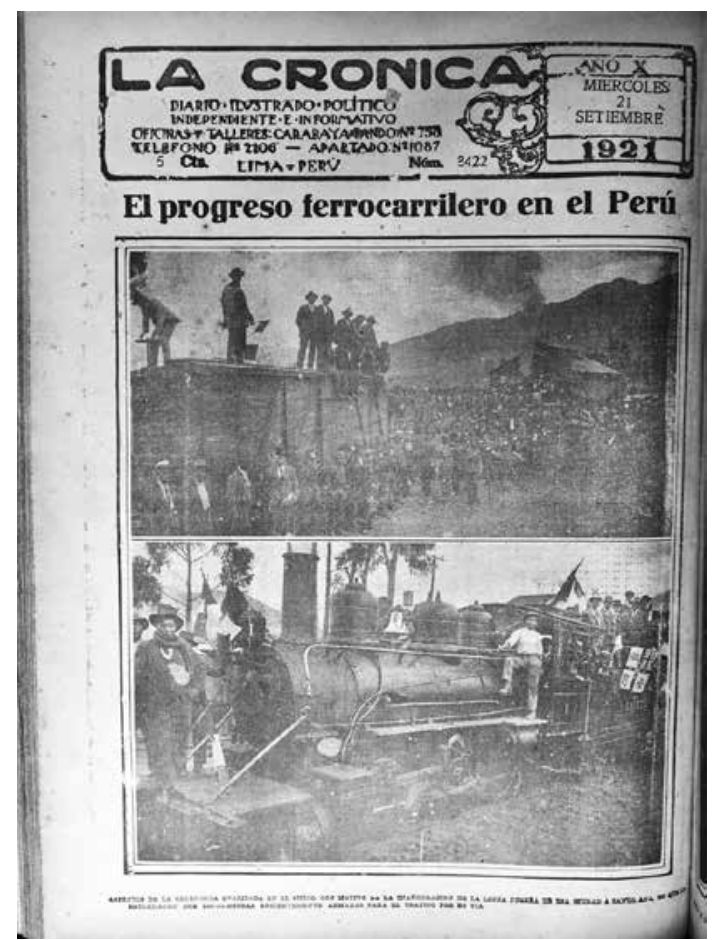

Figura 14. Diario La Crónica, Lima, 21 de septiembre de 1921.

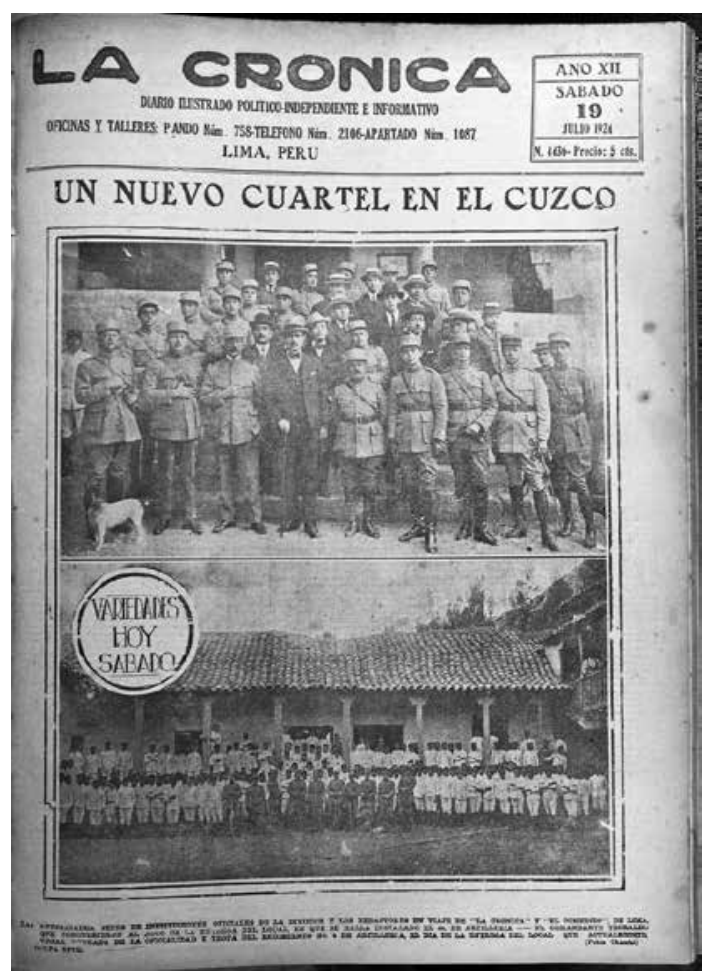

Figura 15. Diario La Crónica, Lima, 19 de julio de 1924. 


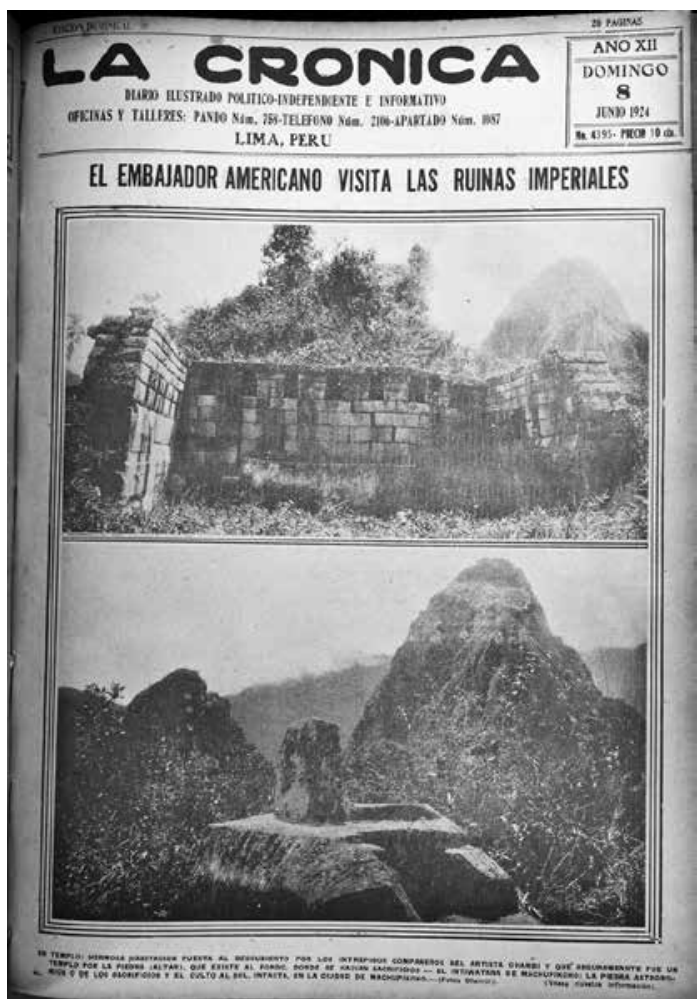

Figura 16. Diario La Crónica, Lima, 8 de junio de 1924.

setiembre de 1925); los avances en la construcción de caminos andinos como la "Carretera Cuzco-AbancayPuquio" (La Crónica, Lima, 12 de junio de 1927) (Figura 17), entre otras informaciones.

Bajo la noción de lo que podríamos entender como fotografía documental, donde se abarca una serie de temas y situaciones no necesariamente de interés noticioso pero sí de interés de actualidad y conocimiento de aspectos culturales, históricos y sociales, Martín Chambi aborda y publica diferentes temáticas de la ciudad y del interior del Cusco. Como ejemplo, vemos los títulos "El Perú pintoresco" con fotografía de la trilla en Sicuani (La Crónica, Lima, 29 de febrero 1920); "Una reliquia incaica" con gran imagen de una esquina de la calle Del Triunfo, en el centro histórico de la ciudad (La Crónica, Lima, 3 de febrero de 1924); "Joyas artísticas de la ciudad imperial" con dos fotografías a color de arquitectura colonial ( $L a$ Crónica, Lima, 27 de julio de 1924) (Figura 18); la arraigada costumbre religiosa cusqueña de "La procesión del Señor de los Temblores en el Cuzco", con dramática fotografía tomada desde un balcón colonial y publicada a página entera en

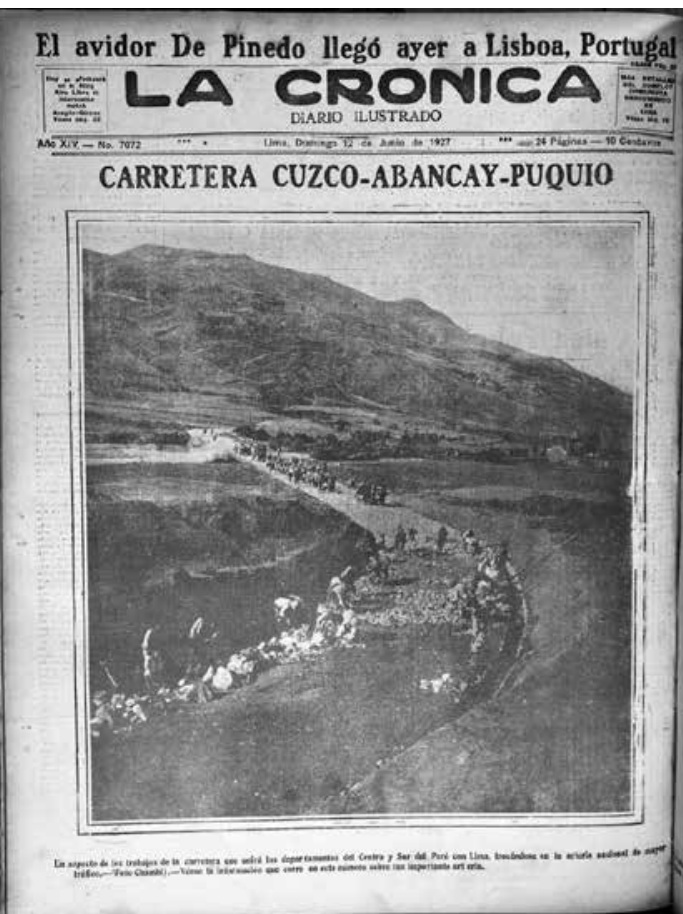

Figura 17. Diario La Crónica, Lima, 12 de junio de 1927.

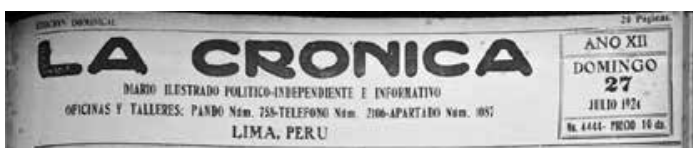

Joyas artísticas de la ciudad imperial

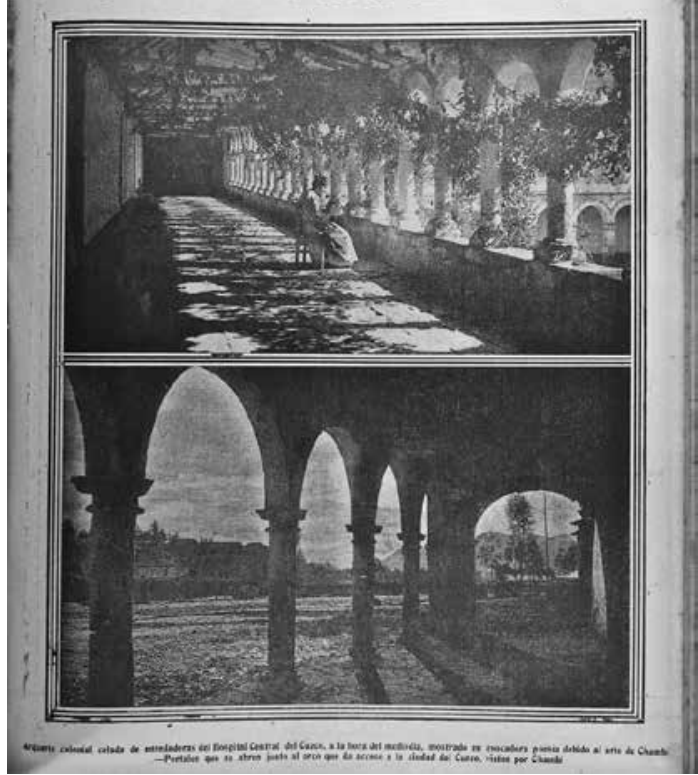

Figura 18. Diario La Crónica, Lima, 27 de julio de 1924. 
contraportada (La Crónica, Lima, 14 de abril de 1927) (Figura 19); y "La vida en la puna peruana" con dos fotografías de carácter social, una de dos niños andinos descalzos en primer plano y la otra, la entrada a una vivienda típica rural con una mujer sentada en el suelo, publicadas en contraportada ( $\mathrm{La}$ Crónica, Lima, 22 de mayo de 1927) (Figura 20).

Es importante enfatizar el mérito de Moral de crear en 1912 un modelo de publicación periodística porque sería la base de una práctica vigente al menos durante dos o tres décadas de fotógrafos peruanos. El caso de Martín Chambi probaría la validez de esta práctica fotográfica acorde a la idea fundacional. Por sus fotografías publicadas en Variedades, pero especialmente por las publicadas en La Crónica, el público se enteraba de lo que acontecía en el sur andino peruano, específicamente en la región cusqueña, así como, también, tomaba conocimiento de las riquezas históricas y culturales de la zona. De hecho, la obra de Chambi en estas publicaciones es una de las pruebas para sustentar que el uso de la fotografía moderna en el terreno informativo y documental en el Perú fue inventado indiscutiblemente en Lima en 1912 por Manuel Moral, bajo la noción de "reporter gráfico".

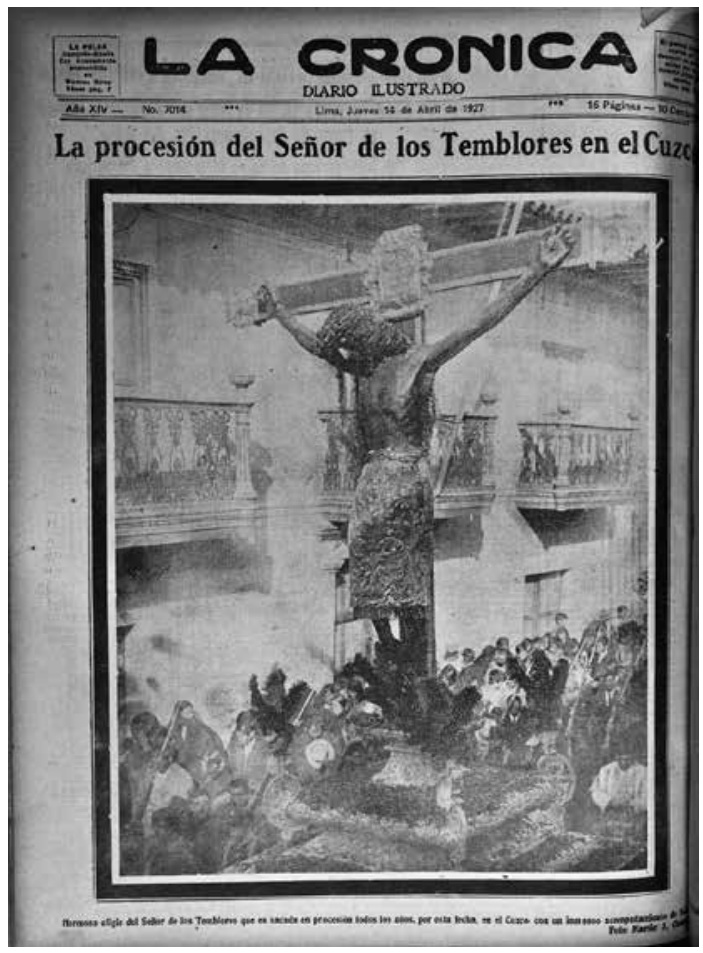

Figura 19. Diario La Crónica, Lima, 14 de abril de 1927.

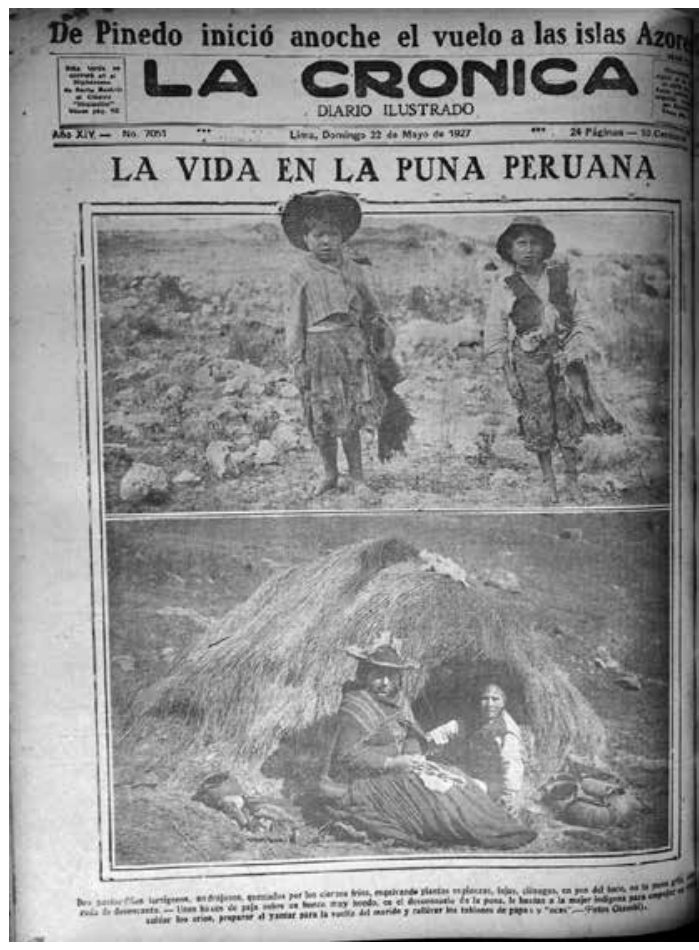

Figura 20. Diario La Crónica, Lima, 22 de mayo de 1927.

\section{Conclusiones}

El fotógrafo portugués afincado en Lima Manuel Moral fue el gran impulsor del periodismo gráfico en el Perú con la fundación de las revistas Prisma (1905), Variedades (1908), La ilustración peruana (1909) y el diario La Crónica (1912), en los que publicó fotografías de una amplia red de fotógrafos afincados en distintas partes del país, que fueron convocados a contribuir en la construcción de una imagen descentralizada del Perú, pero sobre todo a construir una visualidad nacional en toda su complejidad.

Es en abril de 1912, con la aparición del diario La Crónica, cuando se formaliza la noción y práctica del reportero gráfico en el Perú, con la realización de una fotografía de tipo testimonial, de respeto por el registro fotográfico. La noción de reportero gráfico implantada en La Crónica influyó en la agudeza de las miradas de los fotógrafos del interior del país. Esa mirada se centraba en temas de interés nacional, como las obras de progreso, la historia, las costumbres, las visitas ilustres, la arqueología, geografía y las condiciones y modos humanos. 
Analizada retrospectivamente, la visión de Manuel Moral nos obliga a reconocer para la fotografía asociada a publicaciones, y desde la noción acuñada del "reportero gráfico", un lugar mucho más importante del que le habíamos dado en la construcción de la historia de la fotografía peruana.

Es importante señalar, sin embargo, que el oficio de reportero gráfico como trabajo autónomo y en conexión directa y situación de dependencia con el medio impreso -y ya no como una función más cumplida por un fotógrafo propietario de estudio de retrato-, demoraría en aparecer en el contexto periodístico peruano. Este desarrollo será motivo de investigaciones futuras.

\section{Agradecimientos}

A la señora Marilú Cerpa Moral, por darnos acceso a la valiosa documentación familiar de su abuelo Manuel Moral y por el acceso a su colección de revistas y fotografías originales. A Johnny Chávez, Félix Paz, Martín Ugaz, José Cerna Sabogal, Raúl Borda, Cecilia Salgado, Luis Repetto, Gloria Huarcaya Rentería, Jorge Ramírez González del Riego, Herman Schwarz. También a la Casa O'Higgins de la Pontificia Universidad Católica del Perú, a la Municipalidad Metropolitana de Lima, a la Universidad de Piura, al Centro de Documentación del Diario Oficial El Peruano (Lima) y al Centro de la Imagen de Lima. Un agradecimiento aparte a los evaluadores del artículo por su atención y tiempo.

\section{Referencias Citadas}

Alonso, M.

1995 Fotoperiodismo: formas y códigos. Ed. Síntesis, Madrid. Borda, R.

2013 Precursor del fotoperiodismo. En El Peruano, Lima (15 noviembre).

Borda, R.

2014 Lente visionario. En El Peruano, Lima (2 mayo).

Cerna, J.; Garay, A. y Vargas, C.

2012 El terremoto de Piura de 1912. En El Tiempo, Piura (22 julio).

Fernández, R.

1982 Manuel Moral y los días cunares de "La Crónica". En La Industria, Trujillo (25 abril).

Garay, A. y Villacorta, J.

2014 Manuel Moral, fotógrafo y editor: la esfera pública y la imagen de la nación en la Lima del 1900. En Bienal del Fotografía de Lima 2014, Ed. Centro de la Imagen, Lima.
Gargurevich, J.

2011 Introducción a la Historia del Periodismo. Pontificia Universidad Católica del Perú, Lima.

Majluf, N. y Wuffarden, L.

2001 Índice documentado de fotógrafos activos en el Perú 1842-1942. En La Recuperación de la Memoria, Museo de Arte de Lima, Fundación Telefónica, Lima.

Mendoza, M.

2013100 años de periodismo en el Perú. 1900-1948. Fondo Editorial Universidad de Lima, Lima.

Newhall, B.

2002. Historia de la fotografía. Ed. G. Gili, Barcelona.

Sánchez, L.A.

2009 Valdelomar o la Belle Époque. Fondo Editorial del Congreso del Perú, Lima.

Schwarz, $\mathrm{H}$.

2007 Martín Chambi: corresponsal gráfico (1918-1929). En Martín Chambi, Fundación Telefónica y Ed. La Fábrica, Madrid.
Resultado del trabajo de campo de la exposición "Manuel Moral, fotógrafo y editor: la esfera pública y la imagen de la nación en la Lima del 1900", llevada a cabo por los autores en la Casa O'Higgins de la Pontificia Universidad
Católica del Perú, durante la II Bienal de Fotografía de Lima en 2014. La exposición tuvo más de cuarenta mil visitantes en los dos meses que estuvo abierta al público. 
